\title{
Exploratory Study of Ecuadorian Teachers' Understanding of Social Emotional Learning: An Examination of Primary School Teachers ${ }^{1}$
}

Estudio exploratorio de la comprensión de los docentes ecuatorianos sobre el aprendizaje socioemocional: un análisis de los docentes de la escuela primaria

\section{Ximena Burgin, Sheila Coli and Mayra C Daniel2*}

Northen Illinois University, USA

\footnotetext{
1 Received: September 20th 2020/ Accepted: May 18th 2021

2 xrecald1@niu.edu; scoli1@niu.edu,mayra.daniel@gmail.com
} 


\section{Abstract}

Direct instruction of Social Emotional Learning (SEL) has been suggested for improving academic performance and reducing behavioral issues in classrooms (CASEL, 2020). This exploratory study provides insight into how a group of Ecuadorian elementary school teachers define and understand SEL. It examined changes in teachers' perspectives and beliefs about their role in SEL integration in elementary school classrooms, after a full-day workshop focused on SEL integration. Quantitative and qualitative data collected before, during and after the SEL workshop indicated a positive change in the teachers' foundational knowledge of SEL after participation in the workshop; however, there was no observed change in the teachers' perceptions of their role in the actual implementation of SEL. Challenges and future implications for an effective integration of SEL are discussed in this research article.

Key words: Social Emotional Learning; SEL workshop; Professional Development (PD); techers' SEL perspectives; elementary school teachers

\section{Resumen}

Se ha sugerido que la instrucción directa del aprendizaje socioemocional (SEL) puede mejorar el rendimiento académico y puede reducir los problemas de conducta en las aulas (CASEL, 2020). Este estudio exploratorio proporciona información sobre cómo un grupo de maestros ecuatorianos de una escuela primaria definen y comprenden SEL. Este estudio examinó los cambios en las perspectivas y creencias de los maestros sobre su papel en la integración de SEL en las aulas de la escuela primaria, después de un taller de un día completo centrado en la integración de SEL. Los datos cuantitativos y cualitativos recopilados antes, durante y después del taller de SEL indicaron un cambio positivo en el conocimiento esencial de los maestros sobre el SEL después de la participación en el taller; sin embargo, no se observaron cambios en las percepciones de los maestros sobre su rol en la implementación de SEL. En este artículo de investigación se discuten los desafíos y las implicaciones futuras para una integración efectiva de SEL.

Palabras clave: Aprendizaje socioemocional; taller de aprendizaje socioemocional; desarrollo emocional; desarrollo profesional (DP); perspectivas SEL de los maestros; docentes de primaria 


\section{Resumo}

Tem-se sugerido que a instrução direta da aprendizagem sócio emocional (SEL) pode melhorar o rendimento acadêmico e pode reduzir os problemas de conduta nas salas de aulas (CASEL, 2020). Este estudo exploratório proporciona informação sobre como um grupo de professores equatorianos de uma escola primária define e compreendem SEL. Este estudo examinou as mudanças nas perspectivas e crenças dos professores sobre seu papel na integração de SEL nas salas de aulas da escola primária, depois de uma oficina de um dia completo centrado na integração de SEL. Os dados quantitativos e qualitativos recopilados antes, durante e depois da oficina de SEL indicaram uma mudança positiva no conhecimento essencial dos professores sobre o SEL depois da participação na oficina; porém, não se observaram mudanças nas percepções dos professores sobre seu papel na implementação de SEL. Neste artigo de pesquisa se discutem os desafios e as implicações futuras para uma integração efetiva de SEL.

Palavras chave: Aprendizagem sócio-emocional; oficina de aprendizagem sócio emocional; desenvolvimento emocional; desenvolvimento profissional (DP); perspectivas SEL dos professores; docentes de primária 


\section{Introduction}

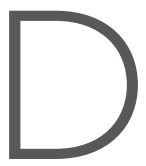

ecades' of research suggest that the better developed students' social and emotional competencies (SEC) are, the greater success they experience in school and life (Bisquerra, 2003; McKown, 2017). Individuals with well-developed emotional skills are more likely to be effective, content, and productive (CASEL, 2020; The Aspen Institute National Commission on Social, Emotional, and Academic Development, 2018). Growing attention from economists and international organizations such as the World Bank (Huerta, 2019) have generated discussions around the importance of promoting the development of such skills in the recent years.

The current COVID-19 pandemic has intensified the educational inequity among students from different socioeconomic backgrounds, especially those from lower income households, as the transition to online learning has cut school supports and resources (National Academies of Sciences, Engineering, and Medicine, 2020). The current situation sharpened disparities related to race, gender, class, and other dimensions of individual and group identity (Jagers, Rivas-Drake, \& Williams, 2019). As such, the need to look at current social and emotional practices that promote optimal developmental outcomes for all learners regardless of their cultural and economic background, has been intensified for educators intent on ensuring equitable instruction for students from different socio-cultural contexts (Yoder et al., 2020),

Ecuador's cultural and linguistic diversity is evident in the country's many living languages and current social issues. Stakeholders in the Ecuadorian educational system are challenged to understand and address cultural diversity (SUMMA, 2020). SEL may offer a foundation for developing diverse students' SEC (Jagers, Rivas-Drake, \& Borowski, 2018). Effective SEL implementation can foster constructive classroom environments where educators can address issues such as privilege, discrimination, social justice, empowerment, and self-determination to bridge the inequalities that underserved communities face (Jagers, Rivas-Drake, \& Williams, 2019). However, aappropriate SEL instruction requires and begins with informed teachers' who know how to overcome obstacles to their students' social, emotional, and cognitive development (Schonert-Reichl et. al., 2017; Taylor \& Larson, 1999).

Given this gap, this study explored Ecuadorian elementary teachers' sensitivity and acceptance of SEL as a component for successful schooling. It examined how the participants' definitions of SEL changed after a full-day workshop aimed at providing educators with foundational understanding about integrating SEL in regular classrooms. 


\section{Theoretical Framework}

\section{SEL in Latin America and in the context of Ecuador}

According to the Collaborative for Academic, Social, and Emotional Learning (CASEL, 2020), SEL involves processes through which individuals develop social and emotional competencies in five areas: self-awareness, self-management, social awareness, relationship skills, and responsible decision-making.

Growing attention from economists and international organizations such as the Andean Development Corporation (CAF), the World Bank, the Inter-American Development Bank (IDB) and the Organization for Economic Co-operation and Development (OECD) (Revista Educación, 2017; Huerta, 2019) have boosted political discussions around the importance of promoting the development of social and emotional skills. Most evidence regarding SEL is based on empirical and longitudinal studies in developed countries, while evidence is scarce in Latin America. Some studies (Bassi et al., 2012; Cunningham et al., 2016; Berniell et al., 2017) confirm the importance of these competences in educational and labor outcomes.

In Latin America, the publication of the IDB's "Disconnected" report (Bassi, 2012) as well as the publication of the report "More Skills for Work and Life" by the CAF report (Berniel et al., 2017) had a significant impact in the region.. The authors of Disconnected highlighted that schools in Latin America are not developing the skills children and young people need to be successful in the workplace and face the demands society requires (Bassi et al., 2012). Bassi et al. (2012) made an urgent call to focus efforts on improving both the quality and relevance of education systems and stressed that only in this way can the existing disconnection between the school and the labor market be mitigated. Similarly, the CAF report stated that Latin America needs to increase its efforts in the development of a set of skills that allows young people to navigate and adapt to the changing environments of the years to come (Berniel et al., 2017). The international evidence shows the importance these skills have on learning and on the present and future achievements of students.

A few Latin American countries such as Peru, Colombia, Ecuador, Argentina, and Uruguay explicitly mention SEL in their curriculum (Revista Educación, 2017; INEED, 2020). Most consider transversal skills such as communication and collaborative work. They have been working to develop frameworks for the integration of SEL in the classroom (INEED, 2020). However, teachers in Latin America are concerned about the necessary training to deliver effectively SEL instruction (Revista Educación, 2017). 


\section{Diversity in Ecuador and the Need for SEL}

Direct SEL instruction has been positively associated with subjective well-being, engaged citizenship, academic performance and success, salary level, etc. (Bisquerra, 2003; Bridgeland et al., 2013; Busso et al., 2017; CASEL, 2020; Durlak et al., 2011; Elias et al., 1997; Goodman et al., 2015; Roffey, 2017; Schonert-Reichl et al., 2017; Zins, 2004). Due to Ecuador's diversity, the country's educators' work requires consideration of the sociocultural context of schools and communities, as well as of the support available to stakeholders whose goal is to validate all learners' rights (Van Damme et al., 2013).

Ecuador's cultural and linguistic diversity is evident in the country's many living languages. According to Ethnologue (2020), there are 21 indigenous languages (e.g., Cofán, and Quechua) (Constitución Política del Ecuador, 1998). Ecuador's National Institute of the Census (Instituto Nacional de Estadísticas y Censos, 2015) documented 93\% of Ecuador's population speaks Castilian and 4.1\% speak Quechua. Census information shows the country's population was composed of $71.9 \%$ mestizos (mixed Amerindian and white), 7.4\% Montubio, 7\% Amerindian, 6.1\% white, 4.3\% Afroecuadorian, $1.9 \%$ mulato, $1 \%$ black, and $0.4 \%$ other (INEC, 2015). Thus, stakeholders in the Ecuadorian educational system are challenged to understand and address cultural diversity (SUMMA, 2020). Because SEL promotes awareness about disparities in schooling, opportunity gaps, and the history of unequal schooling (Gregory \& Fergus, 2017), the researchers posited that it would contribute to equitable schooling in Ecuador. SEL promotes awareness about disparities in schooling, opportunity gaps, and the history of unequal schooling (Gregory \& Fergus, 2017). Thus, these researchers posited that SEL will contribute to provision of equitable schooling in Ecuador.

\section{Teacher Training for the Integration of SEL}

Research has recognized the key role teachers play in modeling and providing students with tools to develop SEL and in creating nurturing learning environments (Bisquerra, 2011; Elias et al., 1997; Taylor \& Larson, 1999; Waajid et al., 2013). The philosophy underpinning an intervention, the beliefs as well as the skills of teachers, are some of the implementation factors that promote or hinder the efficacy of SEL. In its support of the rights of all students, SEL ensures educators create environments that acknowledge diversity as a strength. Hence training is key to improving teachers' knowledge of SEL and their ability to apply it (Castillo et al., 2013; Roffey \& McCarthy, 2013; Talvio et al., 2013; Shulman \& Sherin, 2004;).

Educational reforms require teachers to change their practice, and for that to effectively occur, teachers need to understand and internalize the theory underlying 
the proposed change (Shulman \& Sherin, 2004). Providing Ecuadorian teachers with foundational knowledge of SEL could increase the likelihood of successful reforms. Effective professional development $(\mathrm{PD})$ programs integrate professional learning focused on SEL as well as other areas that embed SEL practices and concepts into the classroom (CASEL Resource District Center, 2020). Therefore, elementary Ecuadorian teachers need opportunities to acquire foundational knowledge about SEL, understand why it is necessary, and master ways to start infusing it in their schools and classrooms.

\section{Multiculturalism in Education}

Teachers' ability to promote affirming classroom environments for diverse contexts is affected by their perceptions of their culture and their awareness of how their cultural norms influence their professional endeavours (Groulx \& Silva, 2010). Culturally responsive educators do not privilege some groups of students and disadvantaging others. (Hawkins \& Norton, 2009; Kincheloe, 2008). This work considers that preparing educators to deliver culturally responsive curricula is key for a nation with Ecuador's students (Banks, 1981, 2014; Buckelew \& Fishman, 2011; Nieto, 2018).

\section{Methodology}

This exploratory study used a mixed-method approach of data collection. Quantitative data were gathered through a six-point Likert scale survey, and qualitative data were gathered in two focus group discussions and open-ended questions. Data was collected before, during and after the SEL workshop. The following research questions guided the study:

RQ1 What are Ecuadorian elementary school teachers' definitions and understanding of SEL in the classroom?

RQ2 How do the teachers' definitions of SEL change due to participation in a workshop focused on SEL?

RQ3 How do teachers perceive the importance of the components of SEL as impacted by a workshop?

\section{Participants}

A sample of 20 credentialed elementary Ecuadorian teachers participated in a full-day workshop on SEL that provided foundational knowledge about SEL: what it 
is, why it is necessary, and how to start effectively integrating it into the classroom. This workshop was part of a series of teacher (PD) workshops. Two focus groups were conducted before the SEL workshop to investigate the participants' understanding of SEL concepts by discussing three questions: (1) how teachers define SEL, (2) how they apply it in the classroom, and (3) what kind of PD or training they have received to integrate SEL in the classroom. These data were used to answer RQ1.

Two open-ended questions were included in the post-test, one of which asked teachers to define SEL. These data were collected and analyzed. Two hands-on activities were included to promote active participation and reflection among the participants. During both activities, teachers were asked to write down their thoughts while discussing in small groups and then share them with the whole group. Audio recordings of these presentations as well as the notes taken during the activities were analyzed. These data together with the open-ended questions were used to answer RQ2.

A researcher-developed survey consisting of 20 6-point Likert-scale items was administered before (pretest) and after (posttest) the workshop. Items 1 to 20 refer to different components of SEL and its integration. Data collected from the pre and posttests were used to answer RQ3. The items of the survey were developed to explore the predisposition of the participants toward SEL. Items utilized constructs including an SEL overview, the main contribution of SEL integration, a mindfulness overview, SEL integration, and attitudes toward SEL integration.

Descriptive statistics (mean, median, and standard deviation) provided basic features to summarize the obtained data. Wilcoxon's test was run to calculate and compare the difference between the data obtained from the pre and post-tests of the quantitative data. Regarding qualitative data, a constant comparison analysis technique was utilized to determine the themes and to cross-reference them with domains from the literature. The constant comparison process was chosen because it allows for coding of the data based on meaningful parts of the text and comparison of the codes to form themes (Glaser \& Strauss, 1967; Leech \& Onwuegbuzie, 2007; Miles et al., 2014).

\section{Results}

RQ1: What are Ecuadorian elementary school teachers' definitions and understanding of SEL in the classroom?

Participants were asked to define SEL and share what they know about it in the pre workshop focus group discussions. Two patterns can be identified. The first pattern refers to strategies to keep students busy to alleviate family problems. Most 
of the teachers agreed that SEL is some kind of "game" or "expression of affection" so students keep their minds off their family problems and are able to focus in class. All the participants agreed that students' family problems could affect their attention and work in class. The second pattern refers to the teachers' awareness and understanding of students' backgrounds. Most of the teachers related SEL to the ability to recognize and understand the reasons for students' behavioral changes. One of the focus groups related SEL with the concept of self-esteem. When asked about SEL, this group of teachers said "SEL has to do with the lack of self-esteem that comes from home. Home is where they [students] build that [self-esteem], and that self-esteem reflects the situation at home." Also, they highlighted the importance of the quality of the relationship of students with their parents and teachers and the effect it has on students' learning.

When asked whether they apply any knowledge or concepts of SEL in their lesson plans, participants in the focus group did not provide information to indicate how SEL is incorporated into their lesson plans. Most of them expressed that based on their observations, they adapt their lessons to promote students' interest as well as to create a safe learning environment. One teacher indicated, "When a student was a good student the previous year and this year the student is not performing academically, I inquired with the parents about the home situation, with other teachers, and counselors to determine the cause. I used this information to support the student emotionally through my lesson plans." Another teacher expressed: "Teachers should make the student feel good and motivated, interested. [So they can say] 'I like this'."

Finally, participants were asked about their previous training on SEL. All of them agreed they received some type of PD courses or training to learn about neuroeducation, educational psychology and/or emotions. One of the teachers suggested that these trainings were "rather superficial," while another teacher added that she would like to receive training directly related to her job as a preschool teacher. In addition, some participants agreed they did not receive any formal education related to SEL, while others referred to their psychology courses in their undergraduate programs. One teacher added that the school psychologists are the agents responsible for assessing students' emotional development. Another teacher mentioned the lack of support from school administrators and from the students' families. Other teachers agreed that measures taken to improve student behavior were not effective because "results are not seen" or "there is no follow-up."

RQ2 How do these teachers' definitions of SEL change due to participation in a workshop focused on SEL?

During the focus group, teachers mainly related SEL to teachers' responsibility in their work to boost students' self-esteem, motivation and interest to learn, all of which can be affected by family problems. Notes and recordings from the first activity 
of the workshop, which included five groups, document that teachers refer to SEL using some of the concepts discussed during the workshop. Each group had to identify three concepts to define SEL. Nine out of the 15 terms selected referred to three of the core competencies presented: self-awareness, responsible decision-making, and relational skills. Five of these terms referred to the self-regulation skill; that is, four out of the five groups agreed that "self-regulation," "learning how to behave," or "thinking before acting" are the key terms that define SEL. The other selected terms referred to terms used throughout the first part of the workshop such as emotions, knowledge, participative method, planning, and guidance, indicating a change in these teachers' use of language or terminology to define SEL after the workshop. Before the workshop, the teachers used vague language to provide a definition of SEL, while after the workshop they included and defined specific concepts associated with the core competencies presented. When each of the groups shared the terms, they read their notes aloud; some of them explained briefly the definition of self-regulation. Two of the groups agreed that the terms they chose were based on the SEL definition discussed during the workshop. When asked to select three feelings/emotions that promote student learning, four out of the five groups mentioned happiness and/or academic content. Some teachers explained that this could be achieved through good student-teacher rapport or by allowing students to participate in the class content selection. Three of the groups selected empathy as a key emotion to promote student learning, while two mentioned a safe learning environment. Some other groups selected negative feelings such as frustration, fear, sadness, anger, and confusion; they explained these feelings can help teachers and students identify areas to work on.

During the second hands-on activity, teachers were divided into five groups and asked to select one of the seven practical class activities presented in the workshop (identifying similarities and differences; sharing thorns and roses; reading to identify and/or roleplay writer's emotions; writing to oneself; practicing mindfulness through breathing, silence and concentration; creating the corner of emotions; and teaching through positive examples) and explain possible positive results they would expect as well as possible challenges of implementation. Two groups selected "sharing thorns and roses," two selected "creating the corner of the emotions," and one decided to discuss "teaching through positive examples." Regarding the "thorns and roses" activity - an activity in which students are encouraged to share a negative and a positive aspect of their day and something to which they are looking forward, the groups claimed as positive that students would share their emotions. One of the groups said this would help the teachers to recognize the personal struggles the student is facing: "We will know what's happening to them." As challenges, both groups expressed positive consequences such as "improve their self-regulation," "solve conflicts," and "identify their own emotions." However, when the researcher inquired about the implementation challenges, they agreed there would not be an implementation challenge, although the challenge to achieve the positive results would be that students express their emotions naturally and allow the teacher to be a participant and try to help them when possible. The groups 
that selected the use of a corner of the emotions (a quiet area of the classroom for students to do activities that will help them regulate their emotions and return to the classroom activities productively) to enhance the social and emotional competencies (SEC) agreed students would develop aspects related to their self-awareness and selfregulation such as recognizing, expressing and managing emotions.

Regarding challenges, teachers also outlined actions that could be considered positive outcomes such as academic improvement and SEC development. However, when asked for clarification, some teachers explained that teachers need to teach in different ways to cater to different students. Other teachers agreed that students have difficulties focusing on an activity and calming down and reflecting on their actions. Finally, the other group discussed the "teaching through positive examples" activity, that is, using positive language and always pointing out good behavior. This group of teachers believed this activity would improve students' motivation and academic development. However, they agreed there could be some technical problems or lack of resources. Overall, results for activity 2 showed teachers' general understanding of the activity and its relationship with SEL; however, teachers did not clearly express what challenges and/or more concrete outcomes these activities would have on their students and classroom as a whole.

Four main types of definitions can be identified in the teachers' responses to the open-ended questions on the survey. Nine out of the 17 respondents defined SEL, referring to one or more of the core competencies discussed during the workshop. Most of them referred to the development of the responsible decision-making competency; others referred to self-awareness and/or social awareness competencies. Four teachers defined SEL as a tool or a method that teachers use to help students. Two teachers defined SEL as a "set of emotions" that has a positive impact on the students and on the classroom ambiance. Finally, two teachers referred to SEL as "humanistic, consistent, and for all"; these three words were used in the workshop to describe approaches to integrate SEL in classrooms.

RQ3 How do teachers perceive the importance of the components of SEL as impacted by a workshop?

Data collected from the pre- and post-tests suggest this group of Ecuadorian teachers agreed on the importance of SEL and its integration in classrooms. Table 1 shows a slight increase in the teachers' agreement with Q1, Q2, and Q3 when referring to the overview of SEL. The median $(M D)$ scores show an increase in the values from agree to strongly agree, which demonstrates a slight change in teachers' understanding of the theoretical foundation of SEL. This change in Q1, Q2, and Q3 may indicate teachers' increased understanding of the impact of SEL in relationship building and academic performance. 
Table 1. Social Emotional Learning (SEL) Overview

\begin{tabular}{|l|c|c|c|c|c|c|}
\hline & \multicolumn{3}{|c|}{ Pretest } & \multicolumn{3}{c|}{ Posttest } \\
\hline Question & M & MD & SD & M & MD & SD \\
\hline $\begin{array}{l}\text { Q1.Teaching social emotional skills helps } \\
\text { improve the relationships among students. }\end{array}$ & 5.40 & 5.00 & 0.50 & 5.72 & 6.00 & 0.46 \\
\hline $\begin{array}{l}\text { Q2.Teaching social emotional skills helps } \\
\text { improve the relationships between teachers } \\
\text { and students. }\end{array}$ & 5.45 & 5.00 & 0.51 & 5.72 & 6.00 & 0.46 \\
\hline $\begin{array}{l}\text { Q3.Teaching social emotional skills helps } \\
\text { improve students' academic performance. }\end{array}$ & 5.50 & 5.50 & 0.51 & 5.67 & 6.00 & 0.49 \\
\hline
\end{tabular}

Scale: Strongly Disagree=1; Disagree=2; Somewhat Disagree=3; Somewhat Agree=4; Agree $=5$; Strongly Agree $=6$

Table 2 shows a slight increase in the values of the mean scores for Q4 $\left(M_{\text {pretest }}=\right.$ $\left.5.35 ; M_{\text {posttest }}=5.50\right)$ and Q5 $\left(M_{\text {pretest }}=5.35 ; M_{\text {posttest }}=5.50\right)$. This indicates a little change in the teachers' agreement with the contribution of SEL to the classroom environment and the development of students' SEC. However, Q6 shows a slight decrease $\left(M_{\text {pretest }}\right.$ $=5.40 ; M_{\text {posttest }}=5.22$ ) in the teachers' agreement about the contribution of SEL for promoting collaboration between parents and teachers. This decrease in agreement could be explained through the qualitative data, which provides evidence of the lack of support from families and the difficulties teachers face to engage students in the learning process.

Table 2. Main contribution of SEL integration

\begin{tabular}{|l|c|c|c|c|c|c|}
\hline & \multicolumn{3}{|c|}{ Pretest } & \multicolumn{3}{c|}{ Posttest } \\
\hline Question & M & MD & SD & M & MD & SD \\
\hline $\begin{array}{l}\text { Q4. The main contribution of SEL is that it } \\
\text { provides the student with a space in which to } \\
\text { express their feelings freely. }\end{array}$ & 5.35 & 5.00 & 0.49 & 5.50 & 6.00 & 0.71 \\
\hline $\begin{array}{l}\text { Q5.The main contribution of SEL is that } \\
\text { it enhances the student's academic and } \\
\text { personal success through the development of } \\
\text { social and emotional competencies. }\end{array}$ & 5.40 & 5.00 & 0.50 & 5.61 & 6.00 & 0.50 \\
\hline $\begin{array}{l}\text { Q6.The main contribution of SEL is that it } \\
\text { encourages teachers and families to work } \\
\text { together in a systematic way. }\end{array}$ & 5.40 & 5.00 & 0.60 & 5.22 & 5.00 & 0.81 \\
\hline
\end{tabular}

Scale: Strongly Disagree $=1$; Disagree $=2$; Somewhat Disagree $=3$; Somewhat Agree $=4$; Agree=5; Strongly Agree $=6$ 
Table 3 shows Q7, Q8, and Q9 regarding the main objectives of mindfulness. Both Q7 and Q8 show a slight increase in the mean scores and the median, indicating change in teachers' understanding of the outcomes of integrating mindfulness in their classrooms, while Q9 show a very small decrease in the values of the mean scores and no change in the median values $\left(M_{\text {pretest }}=5.60 ; M_{\text {posttest }}=5.56 ; M D_{\text {pretest }}=6.00 ; M D_{\text {posttest }}\right.$ $=6.00$ ). This could indicate that teachers' view of the effect of mindfulness in students' interpersonal skills did not change due to the workshop.

Table 3. Mindfulness overview

\begin{tabular}{|l|c|c|c|c|c|c|}
\hline & \multicolumn{3}{c|}{ Pretest } & \multicolumn{3}{c|}{ Posttest } \\
\hline Question & M & MD & SD & M & MD & SD \\
\hline $\begin{array}{l}\text { Q7.The main objective of integrating } \\
\text { mindfulness in the classroom is to make the } \\
\text { student feel comfortable in class through } \\
\text { relaxation activities. }\end{array}$ & 5.30 & 5.00 & 0.57 & 5.50 & 6.00 & 0.71 \\
\hline $\begin{array}{l}\text { Q8.The main objective of integrating } \\
\text { mindfulness in the classroom is to improve } \\
\text { students' attention and concentration } \\
\text { capacity. }\end{array}$ & 5.40 & 5.00 & 0.50 & 5.67 & 6.00 & 0.49 \\
\hline $\begin{array}{l}\text { Q9.The main objective of integrating } \\
\text { mindfulness in the classroom is to foster the } \\
\text { development of interpersonal skills. }\end{array}$ & 5.60 & 6.00 & 0.50 & 5.56 & 6.00 & 0.51 \\
\hline
\end{tabular}

Scale: Strongly Disagree=1; Disagree=2; Somewhat Disagree=3; Somewhat Agree=4; Agree $=5$; Strongly Agree $=6$

Table 4 shows six survey items (Q10, Q11, Q12, Q13, Q14, Q15) referring to the effective integration of SEL in the classroom and the role of the teacher. Q11, Q14, and Q15 had a change in the mean scores, indicating teachers' change in their agreement about considering emotions in student assessment as well as considering appropriate student behavior and the engagement of other institutional actors for effective SEL implementation. There was little or no change in Q10, Q12, and Q13, indicating that teachers' views about making goals explicit and pointing out "correct" and "incorrect" student behavior did not vary due to the workshop. 
Table 4. SEL Integration

\begin{tabular}{|l|c|c|c|c|c|c|}
\hline & \multicolumn{3}{|c|}{ Pretest } & \multicolumn{3}{c|}{ Posttest } \\
\hline Question & M & MD & SD & M & MD & SD \\
\hline $\begin{array}{l}\text { Q10.For an effective integration of Social } \\
\text { Emotional Learning, the teacher should } \\
\text { make socioemotional learning objectives } \\
\text { explicit. }\end{array}$ & 5.11 & 5.00 & 0.94 & 5.11 & 5.00 & 0.76 \\
\hline $\begin{array}{l}\text { Q11.For an effective integration of Social } \\
\text { Emotional Learning, the teacher should } \\
\text { consider students' emotions in their } \\
\text { evaluation. }\end{array}$ & 4.90 & 5.00 & 0.97 & 5.39 & 6.00 & 0.78 \\
\hline $\begin{array}{l}\text { Q12.For an effective integration of Social } \\
\text { Emotional Learning, the teacher should } \\
\text { point out "correct" behavior of students. }\end{array}$ & 5.20 & 5.00 & 0.83 & 5.17 & 5.00 & 0.79 \\
\hline $\begin{array}{l}\text { Q13.For an effective integration of Social } \\
\text { Emotional Learning, the teacher should } \\
\text { point out “incorrect" behavior of students. }\end{array}$ & 3.30 & 3.00 & 1.84 & 3.33 & 2.50 & 2.13 \\
\hline $\begin{array}{l}\text { Q14.For an effective integration of Social } \\
\text { Emotional Learning, the teacher should not } \\
\text { ignore inappropriate classroom behavior. }\end{array}$ & 3.75 & 4.50 & 2.12 & 4.28 & 4.50 & 2.03 \\
\hline $\begin{array}{l}\text { Q15.For an effective integration of Social } \\
\text { Emotional Learning, the teacher should } \\
\text { involve all institutional actors. }\end{array}$ & 5.05 & 5.00 & 1.32 & 5.35 & 5.00 & 0.61 \\
\hline
\end{tabular}

Scale: Strongly Disagree=1; Disagree=2; Somewhat Disagree=3; Somewhat Agree $=4$; Agree $=5$; Strongly Agree $=6$

Table 5 shows a slight increase in the values of each of the mean scores, indicating teachers' stronger agreement about their role in the integration of SEL after their participation in the workshop. 
Table 5. Attitude towards SEL integration

\begin{tabular}{|l|c|c|c|c|c|c|}
\hline & \multicolumn{3}{|c|}{ Pretest } & \multicolumn{3}{c|}{ Posttest } \\
\hline Question & M & MD & SD & M & MD & SD \\
\hline $\begin{array}{l}\text { Q16.I feel comfortable teaching social } \\
\text { emotional skills to students. }\end{array}$ & 4.90 & 6.00 & 1.77 & 5.41 & 6.00 & 0.71 \\
\hline $\begin{array}{l}\text { Q17. I feel comfortable sharing my emotions } \\
\text { with my students. }\end{array}$ & 4.75 & 5.00 & 1.21 & 5.39 & 6.00 & 0.78 \\
\hline $\begin{array}{l}\text { Q18.It is my job to help students understand } \\
\text { and manage their emotions. }\end{array}$ & 5.30 & 5.00 & 0.73 & 5.72 & 6.00 & 0.46 \\
\hline $\begin{array}{l}\text { Q19. It is my job to help students develop } \\
\text { their social-emotional competencies. }\end{array}$ & 4.95 & 5.00 & 1.05 & 5.59 & 6.00 & 0.62 \\
\hline $\begin{array}{l}\text { Q20.It is my job to assess my students' } \\
\text { personal development. }\end{array}$ & 4.15 & 5.00 & 1.66 & 5.11 & 5.50 & 1.41 \\
\hline
\end{tabular}

Scale: Strongly Disagree $=1$; Disagree $=2$; Somewhat Disagree $=3$; Somewhat Agree $=4$; Agree $=5$; Strongly Agree $=6$

A Wilcoxon signed ranks test was run; however, the results showed no significant difference $(\mathrm{Z}=1.93, \mathrm{p}=.073)$ between the scores obtained from the pre- and post-tests. This result may be explained due to the length of the workshop and the need for more in-depth PD on the SEL concepts and its impact on students' emotional and academic development.

\section{Findings}

Results suggest that teachers benefited from the SEL workshop. Although the quantitative data did not produce any statistical significance from pre to post-test to show a difference in the responses; the qualitative data generated evidence of the changes in the knowledge among participants regarding the SEL concepts and their integration in the classroom. During the focus group discussions, the participants indicated their perception that a relationship exists between SEL, self-esteem and love. However, by the end of the workshop, participants were able to discuss selfmanagement, self-awareness, and responsible decision-making while expressing proper SEL terminology to help with students' development of SEC. The participants' SEL definitions were not clearly presented before the workshop; however, after the workshop, the participants discussed self-regulation terms and the management of emotions and knowledge to obtain positive results in the classroom. The participants' 
definitions before the workshop related to the students' emotions as opposed to the development of skills and knowledge to manage one's emotions as it is defined in the field. This lack of alignment indicates the limited understanding of the definition of SEL and the SEL components for effective implementation in the classroom. The teachers indicated the importance of incorporating these concepts to identify and provide needed supports. This indicates that the workshop provided these teachers with a relevant and necessary theoretical background for a more effective discussion of SEL.

Regarding the integration of SEL in the classroom, the quantitative data showed a slight change in the mean $(M)$ and median $(M D)$ scores for some of the survey items (see Table 4 and Table 5) related to the participants' knowledge of integrating SEL. However, the qualitative data indicated gaps in the comprehension of SEL concepts and its implementation as part of the lesson plan(s). For example, a group of teachers expressed that being able to understand students' problems/mood at the beginning of the day would help them select the proper strategy to address the students' needs. While the survey data show a slight increase in teachers' understanding of their role in effective SEL implementation, qualitative data indicate that these teachers do not embed any SEL-related concepts, strategies or activities in their lesson plans. In addition, when discussing positive outcomes and expected challenges, this group of teachers was not able to differentiate between challenges and outcomes, thereby showing insufficient knowledge about the implementation of SEL. Hence, while the quantitative data indicated positive changes regarding these teachers' understanding of SEL and the need for its integration in the classroom, the qualitative data seemed to show no change in the teachers' ability to envision the implementation of SEL in real classrooms. This indicates the need for in-depth PD.

Overall, this study provided insight into how a PD workshop may change teachers' understanding and perceptions of SEL, its components, and their own role in its implementation. It also provided evidence of the lack of preparation and knowledge for the effective integration of SEL in the classroom. Although this is a first attempt to explore Ecuadorian teachers' understanding and perspectives of SEL, it serves as a springboard for further discussion to provide Ecuadorian teachers with strategies to integrate SEL into their classrooms. 


\section{Conclusions}

The results of this study suggest the need for further PD to guide teachers in the integration of SEL in classroom instruction. It is key that Ecuadorian teachers have a clear understanding of what SEL is, how to implement it in their own practices, and what their role is in the development of SEC in their students. Teachers' understanding the different concepts involved in SEL will allow them to respond to their student's needs. In addition, SEL knowledge will allow the implementation of teaching strategies as means to improve academic achievement. For effective implementation, further training is needed to provide teachers with the tools to embed SEL in their lesson plans. Then the development of their students' SEC will be intentional and the teachers will be able to identify and tackle challenges in spite of the emotional issues children may be facing at different stages of life. The successful implementation of SEL concepts in the classroom will be driven by the development of goals and objectives per grade level so the students will develop according to their emotional level and needs, providing students with the necessary tools to succeed in the future.

\section{Limitations}

The research tools used for this study may pose a number of limitations that might serve as counter arguments for the contributions of this study; however, this research is a key starting point to understand and support the effective integration of SEL-related PD for secondary school Ecuadorian teachers. In addition, this group of Ecuadorian teachers agreed with the need and benefits of explicitly promoting SEL in teacher PD. This is a modest investment in SEL, but it will certainly pay off for individuals, schools, and our society.

\section{Funding:}

This project was supported by the CREATE Center at Northern Illinois University. 


\section{References}

Banks, J. A. (1981). Education in the 80's: Multiethnic Education. Washington, DC: National Education Press.

Banks, J. A. (2014). Cultural Diversity and Education: Foundations, Curriculum, and Teaching. 6th ed. Boston, MA: Allyn and Bacon.

Bassi, M., Busso, M., Urzúa, S., \& Vargas, J. (2012). Disconnected: Skills, Education, and Employment in Latin America. Inter-American Development Bank.

Berniell, L., Mata, D., Bernal, R., Camacho, A., Barrera-Osorio, F., Álvarez, F., Brassiolo, P., \& Vargas, J. (2017). RED 2016. More skills for work and life: The contributions of families, schools, jobs, and the social environment. Caracas: CAF. http://scioteca.caf. com/handle/123456789/1060

Bisquerra, R. (2003). Educación emocional y competencias básicas para la vida. Revista de Investigación Educativa, 21(1): 7-43.

Bisquerra, R. (2011). Educación emocional. propuestas para educadores y familias. Bilbao: Desclée de Brower.

Bridgeland, J., Bruce, M., \& Hariharan, A. (2013). The missing piece: A national teacher survey on how social and emotional learning can empower children and transform schools. A Report for CASEL. Civic Enterprises.

Buckelew, M., \& Fishman, A. (2011). Reaching and teaching diverse populations: Strategies for moving beyond stereotypes. Los Angeles, CA: Sage

Busso, M., Cristia, J., Hincapié, D., Messina, J., \& Ripani, L. (eds). (2017). Learning better: Public policy for skills development. Inter-American Development Bank.

Castillo, R., Fernández-Berrocal, P., \& Brackett, M. A. (2013). Enhancing teacher effectiveness in Spain: A pilot study of the RULER approach to social and emotional learning. Journal of Education and Training Studies, 1(2): 263-272.

Collaborative for Academic, Social, and Emotional Learning (CASEL). 2020. http:// www.casel.org/

Collaborative for Academic, Social, and Emotional Learning (CASEL): Resource District Center. 2020. https://drc.casel.org/strengthen-adult-sel-competenciesand-capacity/professional-learning/ 
Constitución Política del Ecuador. (1998). Constitución política de la República del Ecuador. Titulo I - De los principios fundamentales (Title I - Fundamental principles). https://www.oas.org/juridico/spanish/mesicic2_ecu_anexo15.pdf

Cunningham, W., Acosta, P., \& Muller, N. (2016). Minds and behaviors at work: Boosting socioemotional skills for Latin America's workforce. The World Bank.

Durlak, J. A., Weissberg, R.P., Dymnicki, A.B., Taylor, R. D., \& Schellinger, K.B. (2011). The impact of enhancing students' social and emotional learning: A meta-analysis of school-based universal interventions. Child development, 82(1): 405-432.

Elias, M. J., Zins, J.E., Weissberg, R.P, Frey, K.S., Greenberg, M.T., Haynes, N.M., Kessler, R. Schwab-Stone, M.E., \& Shriver, T.P. (1997). Promoting social and emotional learning: Guidelines for educators. Alexandria, VA: Association for Curriculum and Supervision Development.

Ethnologue. (2020). Languages of the world. https://www.ethnologue.com/country/ EC/languages

Glaser, B. G., \& Strauss, A.L. (1967). The discovery of grounded theory: Strategies for qualitative research. Chicago: Aldine.

Goodman, A., Joshi, H., Nasim, B., \& Tyler, C. (2015). Social and emotional skills in childhood and their long-term effects on adult life. London: Institute of Education.

Gregory, A., \& Fergus, E. (2017). Social and emotional learning and equity in school discipline. The Future of Children: 117-136.

Groulx, J. G., \& Silva, C. (2010). Evaluating the development of culturally relevant teaching. Multicultural Perspectives, 12 (1): 3-9.

Hawkins, M., \& Norton, B. (2009). Critical language teacher education. In A. Burns \& J. Richards (Eds.). Cambridge guide to second language teacher education, 30-39. Cambridge, England: Cambridge University Press.

Huerta, M. (2019). Evaluación de habilidades socioemocionales y transversales: un estado del arte. http://www.adelante-i.eu/sites/default/files/nota_conceptual_ taller_evaluacion_caf-final.pdf

Instituto Nacional de Evaluación Educativa (INEED). (2020). https://www.ineed.edu. uy/nuestro-trabajo/observatorio-socioemocional.html

Instituto Nacional de Estadísticas y Censos (INEC). (2015). https://bit.ly/1y5pcrD.

Jagers, R. J., Rivas-Drake, D., \& Borowski, T. (2018). Equity and social and emotional learning: A cultural analysis. Chicago, IL: CASEL. 
Jagers, R. J., Rivas-Drake, D., \& Williams, B. (2019). Transformative social and emotional learning (SEL): Toward SEL in service of educational equity and excellence. Educational Psychologist, 54(3), 162-184.

Kincheloe, J. L. (2008). Critical pedagogy primer. New York, NY: Peter Lang.

Leech, N. L., \& Onwuegbuzie, A.J. (2007). An array of qualitative data analysis tools: A call for data analysis triangulation. School Psychology Quarterly, 22(4): 557-584.

McKown, C. (2017). Social-emotional assessment, performance, and standards. The Future of Children, 157-178.

Miles, M. B., Huberman, A.M., \& Saldana, J. (2014). Qualitative data analysis. 3rd ed. London, United Kingdom: Sage Publications, Inc.

National Academies of Sciences, Engineering, and Medicine. (2020). Reopening K-12 schools during the COVID-19 pandemic: Prioritizing health, equity, and communities. Washington, DC: The National Academies Press.

Nieto, S.. (2018). Affirming diversity: The sociopolitical context of schools. 7th ed. New York, NY: Longman.

Revista de Educación. (2017). Desarrollo de habilidades socioemocionales: Una tarea que involucra a los colegios.http://www.revistadeeducacion.cl/desarrollohabilidades-socioemocionales-una-tarea-involucra-los-colegios/

Roffey, S., \& McCarthy, F. (2013). Circle solutions, a philosophy and pedagogy for learning positive relationships: What promotes and inhibits sustainable outcomes? International Journal of Emotional Intelligence, 5(1): 36-55.

Schonert-Reichl, K. A., Kitil, M.F., \& Hanson-Peterson, J. (2017). To reach the students, teach the teachers: A national scan of teacher preparation and social and emotional learning. A report prepared for the Collaborative for Academic, Social, and Emotional Learning (CASEL). Vancouver, BC: University of British Columbia.

Shulman, L. S., \& Sherin, M.G. (2004). Fostering communities of teachers as learners: Disciplinary perspectives. Journal of Curriculum Studies 36 (2): 135-140.

SUMMA Laboratorio de Investigación e Innovación en Educación para América Latina y el Caribe. 2020. https://www.summaedu.org/

Talvio, M., Lonka, K., Komulainen, E., Kuusela, M.,\& Lintunen, T. (2013). Revisiting Gordon's teacher effectiveness training: An intervention study on teachers' social and emotional learning. Electronic Journal of Research in Educational Psychology, 11(3): 693-716. 
Taylor, H. E., \& Larson, S. (1999). Social and emotional learning in middle school. The Clearing House, 72 (6): 331-336.

The Aspen Institute National Commission on Social, Emotional, and Academic Learning. (2018). https://www.aspeninstitute.org/programs/national-commissionon-social-emotional-and-academic-development/

Van Damme, W., Aguerrondo, I., Crespo Burgos, C., \& Robalino Campos, M.. (2013). A story of change: How Ecuador seeks to sustain its development agenda through large scale educational reform. Paper presented at UKFIET International Conference on Education and Development - Education and Development post 2015: Reflecting.

Waajid, B., Garner, P.W., Owen, J.E. (2013). Infusing social emotional learning into the teacher education curriculum. International Journal of Emotional Education, 5 (2): 31-48.

Yoder, N., Posamentier, J., Godek, D., Seibel, K., \& Dusenbury, L. (2020). State efforts to elevate social and emotional learning during the pandemic. https://casel.org/ wp-content/uploads/2020/08/CASEL-CFC-final.pdf

Zins, J. E. (Ed.). (2004). Building academic success on social and emotional learning: What does the research say? Teachers College Press: New York and London. 


\section{Author}

${ }^{*}$ Ximena Burgin is an Assistant Professor at Northern Illinois University. Her research interests relate to culturally responsive classroom by implementing researchbased methodologies to improve students' academic outcomes. She has developed and evaluated a variety of state and federal programs in K-12 education and adult education, leading her to understand the impact of diverse interventions on academic achievement through the employment of different methodological techniques. She has also taught graduate research classes and she has mentored doctoral students throughout the dissertation process to completion.

ORCID: https://orcid.org/0000-0002-3494-569X

Sheila Coli is an experienced English as a Foreign language (EFL) secondary school teacher from Uruguay and a current EdD candidate in the Curriculum and Instruction program at Northern Illinois University. Her research focuses on social emotional learning and teacher development related to teacher's knowledge to implement SEL in the classroom.

ORCID: https://orcid.org/0000-0002-5893-5285

Mayra C Daniel is a Professor at Northern Illinois University, De Kalb, IL, USA. A native of Cuba who emigrated to the United States at age 10, she personally experienced the merit of teachers who support the academic and SEL development of linguistically diverse students. Her work and research are based on the belief that social justice is alive and well in the hearts of all caring educators.

ORCID: https://orcid.org/0000-0003-2702-0071

How to reference this article: Burgin, X., Coli, S., \& Daniel, M. C. (2021). Exploratory Study of Ecuadorian Teachers' Understanding of Social Emotional Learning: An Examination of Primary School Teachers. GIST - Education and Learning Research Journal, 22(1), 125-146. https://doi. org/10.26817/16925777.964 